\title{
I am malala, the girl who stood up for education and was shot by the Taliban
}

\section{Opinion}

I am Malala, The Girl Who Stood Up for Education and was Shot by the Taliban. By Malala Yousafzai with Christina Lamb, London, Weidenfeld \& Nicolson publisher, 2013, pg. 276.

The story 'I am Malala' is beautiful and astonishing story of a little girl having extraordinary courage to break the shackles of patriarchy and raise her voice for girls' education. Malala's voice has the purity, but also the rigidity, of the principled. The memoir brings out the hidden potential of girls where her thirst for education and reform brings her in front of world and praiseworthy. The author powerfully narrates the social, economic, cultural, religious and political hurdles in the way of girls' education. Author of the book Christina Lamb is a veteran British journalist having passion for Pakistan and its relationship with Swat and it's clearly reflected in this book. Story of Malala is not only full of vivid drama but exert powerful message of untapped power of girls and their courage to stand for human rights. Thus the book is a must read for all sections of the society including intellectual galaxy to lovers of drama to politics. The whole story is woven around two main arguments that girls' education is always opposed by dogmatic societies and politics play significant role in religious hatred environment. The book naturally packs in much information about the interwoven political processes of National and International politics and its impact on the lives of citizens. Content of the book is in a smooth flow from soothing impact of charismatic scenery of Swat valley and culture of Pasthtuns to fight of a father facing political and religious pressure for his daughter's education to courageous girl who stood for education and shot in her head by Taliban. The exquisiteness of book is that web of various dimensions of human life are so interwoven that it flows like a theatre in minds of readers. Book is dedicated to all the girls who have faced injustice and been silenced and urge that their voices should be heard loud by the society. I find the book useful for motivation to all those girls and their families who can't stand for their right of education.

The book starts its journey with ethnic beauty of Swat valley before Taliban attacks in Part I of the book. This part consists of eight chapters from different arena of life. Description ranges from portray of poverty and social dilemma related to girl child birth to conservative and destructive nature of Taliban towards girls' education. Author raises pertinent question regarding plight of women and birth of a girl child in society. Author said 'a girl was born in a land where rifles are fired in celebration of son, while daughters are hidden away behind the curtain; their role in life is simply to prepare food and give birth to children.' However, the family of Malala was different and celebrated birth of girl child and put her name after great heroine Malalai or Maikand. The exquisiteness lies in the nature of Swat being called PARADISE having kingdom of mountains, gushing waterfalls and crystal clear lakes. Vanguard nature of Malala's father create positive attitude towards her daughter as well respect for his wife which was very rare in their culture. Contrary to it mother is traditional woman having faith in rituals but pure by heart. Author constructs argument around resist of a father for daughter in a patriarchal society to stand for her rights in every circumstance and at any cost. The framework
Volume 6 Issue I - 2017

\author{
Renu Yadav \\ Department of Education, Central University, India
}

Correspondence: Renu Yadav, Assistant Professor, Department of Education, Convenor-Women Empowerment Cell, Central University of Haryana, Jant-Pali Villages, Mahendergarh, India,Tel 08053722090, Email ryadavrenu@gmail.com

Received: July 03, 2017 | Published: October 30, 2017

is inspiration for all fathers who make their daughters plucky to liberally face the world. Author skilfully correlated national politics which create opportunity for anti government organisations like Taliban to captivate young brains on the name of jihad. The author profusely accentuated bigoted practices against women in families even for small thing like milk, education is talk of other world. Author fabricates discourse around Malala who despite of negative milieus studied and spoke for girls' education. She inherited the passion from her father who toils hard to open school even though he can't meet both ends. Strong contentions were made when he opened school from some Maulana called who called schools as 'brothel' and studying there as 'haram' especially for girls. The wretched conditions of villages without electricity, pity health conditions cause death of many children as infant, big fat weddings like India cause bankruptcy and debts of many families and more aggravated problems for women.

In villages on the name of family rivalry women becomes the scape-goat; as most beautiful women get married to least eligible boy. A pertinent question is raised here that why should a girl's life be ruined to settle a dispute she had nothing to do with? (pg.38). Story draws the attention of readers towards zeal of Malala for free education of street children who live near rubbish humps. The post facto impact of 9/11 and search of Osama Bin Laden by America and NATO create havoc in life of people specially women. The enthralling part of story gyrates around dogmatic nature of 'Mufti' against girls' education that left no stone unturned to convince people with his doctrinaire and rigid ideology on the name of God and teachings of Quran. War between countries divides not only geographical boundaries but its people and their identities too. 1947 war between India and Pakistan left many Hindus as well Muslims with many abrasions for forever. Author doesn't stop the narration here but further builds the dialogue that after inter-religion division it spread to intra-religion as well. Muslims in their own country become IDP (Internally Displaced Person). Author regrets that for these internal conflicts to whom they can blame?

Among the main thematic strands of the book apart from girl education is about influence of Maulana involving religion and politics is an attempt to engage diverse learners and shows wide understanding of author towards current issues. Maulana started sharing his thoughts in lighter notion while talking about health and good habits then turned to opposition of women education in Part-II of the book. Mullah spellbound people and often misinter pretated the 
Quran and issued summons against TV, music, dance and education for girls. The heightened emotional stage is shown through the incidences where teachers left job and don't want to teach girl students. However, the hard nugget fact is that Mullah wants to establish his own empire by authoritarian judicial system. The citizens who are fed up from technical, time taking and money consuming system of courts turns blindly to Talibani courts or 'Shura'. Author tries to exert here that negligence of government and torture of police further connects people to these Maulanas. The female mosques (Largest is Red Mosque) which are counted as only place for women to study were destroyed and women were converted to suicide bombers. The Operation Silent of military was too loud and converted into mass killing and destruction of schools (around 400) by 2008. The book under review makes the readers to appreciate the innate qualities of Malala to become great politician as author says 'even as a toddler you talked like a politician'. Here author sometimes unable to connect the ardour of Malala for girls' education to her ambition to become politician. The story becomes complex when it intermingle many aspects together in the form of national politics, military insensitivity and brutality of Talibans as well inherent qualities of Malala together. Book also create a fantasy when 'Gul Makai' is discussed where experience of people especially girls under Taliban are shared in disguise on radio and blog. The experiences show scrape of women on land of men with Taliban ideology.

Part III constitutes another major plank of the book's thesis including various nuances of terrorism and talibanization. Ex-post facto impact of conflicts create ghastly conditions of viciousness and harassment especially for women. The author tries to craft muddle around Malala when she asks hard questions to President of Pakistan about rehabilitation and education of girls. The focal point of thesis is that our country had so many crises but there is no true leader to represent it. Women in all walks of life are abandoned as missing of husband become curse on her because their own families thrown them out due to property share. Author vigoursly expand significance of education in lives of girls and their fortitude to attain it. As Malala said 'I know the importance of education because my pens and books are taken from me by force, but girls of Swat are not afraid of anyone'. There is an argument which is acceptable to academia and global societies that education of girls can silhouette sustainable development and economy of a country. However, when our pride daughter stepladder towards temple of education is shot with bullet by someone having doctrinaire like Taliban, then what will be reaction of readers? Part-IV of book narrates the story around this question when Malala was shot in her head by talibans in her school van. This horrifying episode brings tears in eyes of readers. How blood spread in van and her journey to hospital create heart rendering memories in the mind of readers. The part bestow mind-numbing journey of a girl who got punishment just because she stood up for education. The story portrays contradictory characters of Dr. Javid and insensitive bureaucracy. Author empathically describes psychological trauma of a family whose daughter is shot by Taliban, who have fear to lose their other family members, poverty and not to accompany their daughter for treatment. Story also narrates positive characters in the form of Dr. Fiona and other doctors who take care Malala when there was no one to take care of her in Queen Elizabaeth hospital.

Every story has some angels and devils that run story and same is true for Malala story. Part V of the book narrates all sufferings, illusions, painful operations where her smile become asymmetrical to greetings from many national and international politician to her role model Angelina Jolly. The narration is so coadhesive that readers engross in the emotions of pain and joy. The author also shows her pain that Taliban who shot her was not caught by military which shows static nature of government machinery. Her stoicism, resilience and support of family are depositing energies in her to regain strength to rebuild the future of girls' education in Swat. Due to astonishing audacity Malala was nominated for Nobel Prize for Peace and is Brand Ambassador of UN for Girls Education. To sum up I want to say that this book having lucid language is must read for academia, drama and politicians. Index of book provided with lot of information. I am convinced with the thesis of author fabricated around girls' education and her valour. Malala's story is gripping, tragic and yet full of hope. Book generate few critical arguments in whole text as unwelcome birth of girl child, struggle of a girl for education, brain wash of citizens on the name of religion, and insensitivity of military and government for their own people. This is a must take away home book for all sections of society ranging from scholastic world to all sections of the society.

\section{Acknowledgements}

None.

\section{Conflict of interest}

The author declares no conflict of interest. 